\title{
Prevalence and risk factors of diabetes mellitus in a central district in Islamic Republic of Iran: a population-based study on adults aged $40-80$ years
}

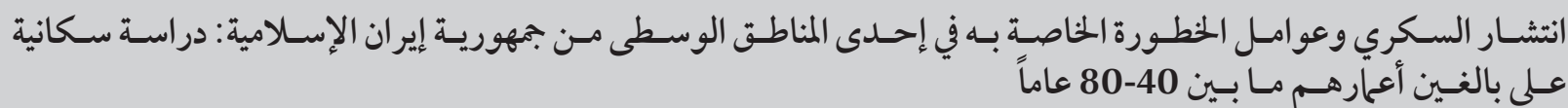

$$
\begin{aligned}
& \text { مرضية كتيبة، سار ا حسيني، رضا سلياني زاد، مسعود رضا معنويت، بهاره خيري، مهدي خبازخوب، نارسيس دفتريان، محمد حسين دهقان }
\end{aligned}
$$

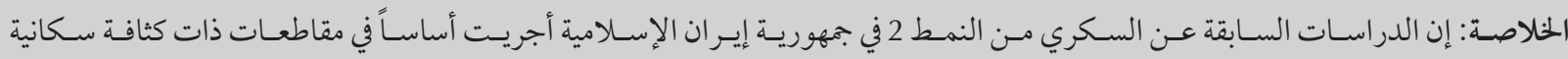

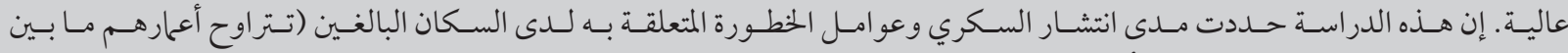

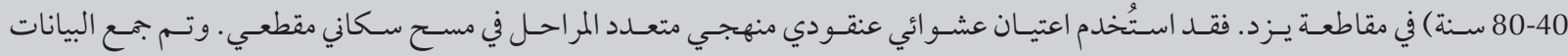

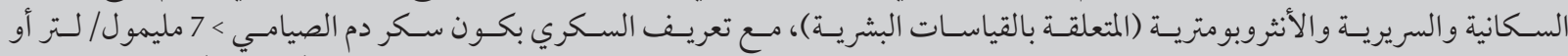

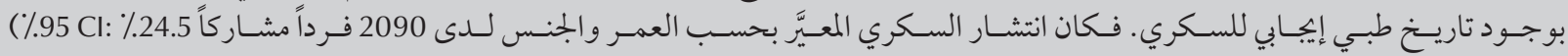

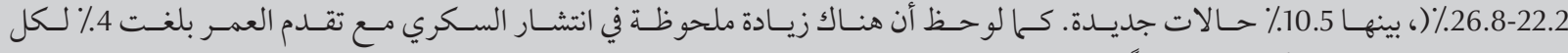

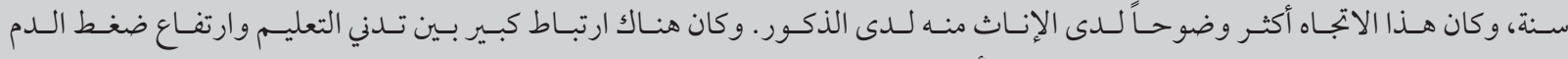

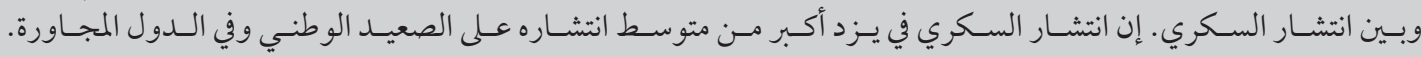

ABSTRACT Previous studies on type 2 diabetes mellitus in the Islamic Republic of Iran were mainly performed in provinces with large populations. This study determined the prevalence and risk factors of diabetes mellitus in an adult population (40-80 years old) from Yazd district. Multistage, systematic cluster random sampling was used in a crosssectional, population-based survey. Demographic, clinical and anthropometric data were collected, with diabetes defined as fasting blood sugar $\geq 7 \mathrm{mmol} / \mathrm{L}$ or a positive medical history of diabetes. The age- and sex-standardized prevalence of diabetes in 2090 individuals participants was $24.5 \%$ (95\% Cl: $22.2-26.8 \%$ ), including $10.5 \%$ new cases. For each year of ageing, the prevalence of diabetes increased significantly by $4 \%$ and this trend was more pronounced in females than males. Low education and hypertension were significantly associated with diabetes prevalence. The prevalence of diabetes mellitus in Yazd is greater than the average levels nationwide and those of nearby countries.

Prévalence et facteurs de risque du diabète sucré dans un district du centre en République islamique d'Iran : étude populationnelle chez des adultes âgés de 40 à 80 ans

RÉSUMÉ Les études antérieures sur le diabète sucré de type 2 en République islamique d'Iran ont été principalement menées dans des provinces très peuplées. La présente étude a déterminé la prévalence et les facteurs de risque du diabète sucré dans une population d'adultes (40-80 ans) du district de Yazd. Un échantillonnage en grappes aléatoire et systématique à plusieurs degrés a été utilisé dans une enquête populationnelle transversale. Des données démographiques, cliniques et anthropométriques ont été recueillies, tandis que le diabète a été défini par un taux de glycémie supérieur ou égal à $7 \mathrm{mmol} / \mathrm{L}$ ou par des antécédents médicaux positifs pour la maladie. La prévalence du diabète normalisée pour l'âge et le sexe chez 2090 participants était de 24,5\% (IC à $95 \%$ : 22,2-26,8 \%), avec 10,5 \% de nouveaux cas. Pour chaque année supplémentaire de vieillissement, la prévalence du diabète augmentait de $4 \%$ et cette tendance était davantage marquée chez les femmes que chez les hommes. Un faible niveau d'études et une hypertension étaient significativement associés à la prévalence du diabète. La prévalence du diabète sucré à Yazd est supérieure aux niveaux moyens à l'échelle nationale et dans les pays voisins.

'Ophthalmic Epidemiology Research Centre; ${ }^{2}$ Ophthalmic Research Centre, Shahid Beheshti University of Medical Sciences, Tehran, Islamic Republic of Iran (Correspondence to M. Katibeh: mdkatibeh@sbmu.ac.ir; mdkatibeh@yahoo.com). ${ }^{3}$ WHO Collaborating Centre for the Eye Health and Prevention of Blindness Programme, Tehran, Islamic Republic of Iran. ${ }^{4}$ Department of Ophthalmology, Shahid Sadoughi University of Medical Sciences and Health Services, Yazd, Islamic Republic of Iran. ${ }^{5}$ Department of Epidemiology, Dezful University of Medical Sciences, Dezful, Islamic Republic of Iran.

Received: 12/07/14; accepted: 10/03/15 


\section{Introduction}

Diabetes mellitus is a prevalent noncommunicable disease worldwide with a high rate of early death in some countries (1). Diabetes affects the quality of life among productive, middle-aged people, and has even been associated with a higher suicide rate (2). Considering disability-adjusted life years, diabetes mellitus has been placed in third or fourth place in the ranking of the global burden of diseases (1) and is therefore considered a major health problem worldwide $(3,4)$.

It has been estimated that the Eastern Mediterranean region (EMR) will have the highest increasing rate in the prevalence of diabetes mellitus after African countries (5). Among the EMR countries, the Islamic Republic of Iran has the second largest population after Pakistan and is predicted to have a high rate of increase in diabetes prevalence until 2030 (5). The economic burden of diabetes is high, accounting for about $10 \%$ of the Iranian national health budget (6).

Previous studies on type 2 diabetes mellitus in this country were mainly performed in Tehran and Isfahan: provinces with the highest populations (7-10). According to a metaanalysis of studies published between 1996 and 2004, the aggregated prevalence of diabetes mellitus in the population aged over 40 years was $24 \%$, and based on the national health profile survey Yazd was identified as a location with a high prevalence of diabetes mellitus (7). The current survey was conducted to provide updated data on the trend of diabetes mellitus in Yazd, taking into account the specific traits of the inhabitants of this desert region in central Islamic Republic of Iran. The results will be beneficial for public health planning and as a baseline for comparison with future epidemiological studies.

\section{Methods}

This study was designed as a crosssectional, population-based survey of residents of urban and rural areas of Yazd, an administrative district of Yazd province (population about half a million). The study was approved by the ethics committee of Shahid Beheshti University of Medical Sciences and the participants took part in the study after giving written informed consent.

\section{Sampling}

The methodology of sampling has been published previously (11). In summary, a multistage, systematic cluster sampling method was used to select a representative sample of the population of the survey area. According to a 2006 national census, the total population of Yazd was around 526000 . The list of all residential regions and blocks was obtained from the Iranian National Statistical Office and used as the sampling frame. Using a stratified and systematic sampling strategy and probability proportional to population density method, 58 clusters were chosen from 251 different residential blocks with each cluster containing 40 persons. In each cluster, eligible samples were recruited with a compact segment sampling method. Finally, 2320 non-institutionalized urban and rural dwellers of Iranian nationality, aged $40-80$ years, who had been living in the district for at least 6 months during the previous year were eligible to enter the study.

\section{Diabetes identification}

Initially, information was obtained about each person's self-reported history of being diagnosed with diabetes mellitus (by a physician) or being prescribed insulin or oral medication for diabetes (by a physician). Then, fasting blood sugar (FBS) was measured by the trained nurses who accompanied fieldwork teams to the participants' homes. The Accu-Chek active glucose meter was used and a fingertip blood sample was taken by needleprick after an overnight fast of at least $8 \mathrm{~h}$. At this stage, FBS was done for all participants who had no history of known diabetes mellitus or were not on insulin or oral diabetic medication. In the second stage, all subjects with diabetes mellitus and those with a FBS $\geq 5.94 \mathrm{mmol} / \mathrm{L}$ on the initial glucometry were referred to a specific laboratory where a venous blood sample was taken; participants were instructed to fast overnight prior to this test.

\section{Other medical assessments}

Blood pressure, weight, height and body mass index (BMI) of all participants were measured and their medical and medication histories were recorded.

The following blood tests were done in this stage: FBS, haemoglobin $(\mathrm{Hb})$, haematocrit (Hct), glycosylated haemoglobin ( $\mathrm{HbAlc}$ ) and fasting serum lipids. A random urine sample was also obtained to measure the albumin/creatinine ratio of urine.

\section{Definitions}

Diabetes mellitus was defined as having 2 separate FBS $\geq 7 \mathrm{mmol} / \mathrm{L}$ or being already diagnosed with diabetes mellitus and/or being on insulin or anti-diabetes medication (12). The first and second FBS tests were measured during the home visit using a glucometer and at a specific laboratory from the venous blood sample respectively. The blood $\mathrm{HbAlc}$ level was measured in participants with diabetes mellitus to determine the average blood glucose and estimate glycaemic control during the previous 2-3 months (12). Impaired fasting glucose (IFG) was defined as FBG level $>6.11$ and $<6.94 \mathrm{mmol} / \mathrm{L}$ (13,14).

The subjects were classified into 6 BMI groups: underweight $(\mathrm{BMI}<$ $18.5 \mathrm{~kg} / \mathrm{m}^{2}$ ), normal weight (BMI $18.5-25 \mathrm{~kg} / \mathrm{m}^{2}$ ), overweight (BMI $25-30 \mathrm{~kg} / \mathrm{m}^{2}$ ), obesity class I (BMI $30-35 \mathrm{~kg} / \mathrm{m}^{2}$ ), obesity class II (BMI 
$35-40 \mathrm{~kg} / \mathrm{m}^{2}$ ) or obesity class III (BMI $>40 \mathrm{~kg} / \mathrm{m}^{2}$ ).

Hypertension was defined as a systolic blood pressure $\geq 140 \mathrm{mmHg}$, diastolic blood pressure $\geq 90 \mathrm{mmHg}(15)$, a self-reported physician-diagnosed history of hypertension, or use of antihypertensive medication.

\section{Analysis}

Crude and adjusted prevalence proportions of diabetes and the $95 \%$ confidence intervals (CI) were reported as the main outcomes in this study. To compute the adjusted prevalence of diabetes among the survey area population, a direct standardization method was used. The age and sex distribution of the Yazd district population was obtained from the Iranian national census in 2006. Logistic regression was used to evaluate the univariate and multivariate relationships of different factors with diabetes considering the cluster design of the study. All statistical analysis was performed by Stata, version 12.0.
$P$-values $<0.05$ were considered statistically significant.

\section{Results}

\section{Background data}

Overall 2320 persons were invited to participate, of whom 2098 agreed to enrol in the study (response rate of $90.4 \%)$. Later, 8 people did not complete the necessary tests for diabetes, giving a final sample of 2090 (response

\begin{tabular}{|c|c|c|c|c|c|}
\hline \multirow[t]{3}{*}{ Variable } & & & \multicolumn{3}{|c|}{ Prevalence of diabetes mellitus } \\
\hline & \multicolumn{2}{|c|}{ Participants $^{\mathrm{a}}$} & \multirow{2}{*}{$\begin{array}{l}\text { New cases } \\
\%(95 \% \mathrm{Cl})\end{array}$} & \multirow{2}{*}{$\begin{array}{c}\text { Known cases } \\
\%(95 \% \mathrm{Cl})\end{array}$} & \multirow{2}{*}{$\begin{array}{l}\text { Total cases } \\
\%(95 \% \mathrm{CI})\end{array}$} \\
\hline & No. & $\%$ & & & \\
\hline \multicolumn{6}{|l|}{ Age (years) } \\
\hline $40-49$ & 802 & 38.4 & $2.3(1.1-3.4)$ & 13.5 (10.7-16.3) & $15.8(12.7-18.8)$ \\
\hline $50-59$ & 705 & 33.7 & $3.5(2.4-4.7)$ & 25.4 (21.9-28.9) & $28.9(25.3-32.5)$ \\
\hline $60-69$ & 337 & 16.1 & $2.7(1.1-4.3)$ & $32.3(27.1-37.6)$ & $35.0(29.3-40.7)$ \\
\hline $70-80$ & 246 & 11.8 & $1.6(0.2-3.1)$ & $35.4(28.5-42.2)$ & $37.0(30.6-43.4)$ \\
\hline \multicolumn{6}{|l|}{ Sex } \\
\hline Male & 992 & 47.5 & $3.1(2.0-4.2)$ & $22.5(19.5-25.5)$ & $25.6(22.4-28.8)$ \\
\hline Female & 1098 & 52.5 & $2.3(1.5-3.1)$ & $23.7(20.8-26.5)$ & $26.0(23.2-28.7)$ \\
\hline \multicolumn{6}{|l|}{ Area } \\
\hline Urban & 1863 & 89.1 & $2.7(2.0-3.5)$ & $21.0(19.1-23.5)$ & $24.0(21.8-26.3)$ \\
\hline Rural & 227 & 10.9 & $2.6(1.6-3.6)$ & $27.6(20.6-35.7)$ & $30.2(22.9-38.7)$ \\
\hline \multicolumn{6}{|l|}{ Education $^{b}$ (years) } \\
\hline Illiterate & 416 & 20.0 & $2.2(1.2-3.9)$ & 34.1 (29.9-38.9) & $36.3(31.4-41.3)$ \\
\hline$<6$ & 850 & 41.0 & $3.6(2.7-4.9)$ & $22.1(19.2-25.3)$ & $25.7(22.6-28.8)$ \\
\hline $6-12$ & 579 & 27.9 & $2.3(1.3-3.9)$ & $16.6(13.3-20.3)$ & $18.9(15.2-22.6)$ \\
\hline$>12$ & 230 & 11.1 & $1.2(0.4-4.0)$ & $16.7(12.7-21.4)$ & $17.9(13.4-22.4)$ \\
\hline \multicolumn{6}{|l|}{ Hypertension $^{b}$} \\
\hline No & 1251 & 60.0 & $1.6(1.1-2.3)$ & $12.2(10.7-13.9)$ & $13.8(12.1-15.6)$ \\
\hline Yes & 834 & 40.0 & $4.7(3.2-6.8)$ & $38.5(34.7-42.2)$ & $43.1(39.3-47.1)$ \\
\hline \multicolumn{6}{|l|}{$B M I^{b}$} \\
\hline Underweight & 34 & 1.8 & 0.0 & $2.9(0-8.9)$ & $2.9(0.0-8.9)$ \\
\hline Normal & 553 & 29.3 & $1.8(0.7-2.9)$ & $23.0(19.4-26.5)$ & $24.8(21.2-28.4)$ \\
\hline Overweight & 797 & 42.2 & $2.9(1.7-4.1)$ & $24.7(21.7-27.7)$ & $27.6(24.5-30.7)$ \\
\hline Obese class I & 383 & 20.3 & $3.1(1.4-4.9)$ & $24.8(20.5-29.1)$ & $27.9(23.4-32.5)$ \\
\hline Obese class II & 100 & 5.3 & $5.0(0.7-9.3)$ & $28.0(19.0-37.0)$ & $33.0(23.6-42.4)$ \\
\hline Obese class III & 21 & 1.1 & $14.3(0-30.6)$ & $23.8(3.9-43.7)$ & $38.1(15.4-60.7)$ \\
\hline \multicolumn{6}{|l|}{ Total } \\
\hline Crude & 2090 & 100.0 & $2.7(2.1-3.3)$ & $23.1(20.9-25.3)$ & $25.8(23.5-28.0)$ \\
\hline Standardized $^{c}$ & - & - & $2.7(2.1-3.4)$ & $21.8(19.5-24.0)$ & $24.5(22.2-26.8)$ \\
\hline
\end{tabular}

aPercentages of total participants $(n=2090) ;{ }^{b}$ Missing data for these variables; ${ }^{\circ}$ For age and sex standardization, data from the Iranian national census 2006 were used.

$C I=$ confidence interval; $B M I=$ body mass index . 
rate of $90.1 \%)$, including 1098 women (52.5\%) and 992 men (47.5\%) (Table 1).

\section{Crude and standardized prevalence of diabetes mellitus}

A total of 539 people were found to have diabetes mellitus, of whom 56 were new (unaware) cases. Thus the crude prevalence of diabetes mellitus in the whole sample was $25.8 \%$ (95\% CI: 23.5-28.0\%), comprising 2.7\% (95\% CI: $2.1-3.3 \%)$ new cases and $23.1 \%$ (95\% CI: 20.9-25.3\%) previously diagnosed (aware) cases of diabetes. The age- and sex-standardized prevalence of diabetes was 24.5\% (95\% CI: 22.2-26.8\%) (Table 1).

\section{Associations of demographic and clinical variables}

The crude prevalence of diabetes was similar in women (26.0\%; 95\% CI: $23.2-28.7 \%)$ and men (25.6\%; 95\% CI: 22.4-28.8\%) (Table 1). Diabetes was more prevalent in older age groups. For example, the crude prevalence of diabetes was $37.0 \%$ (95\% CI: 30.6-43.4\%) among those aged $70-80$ years and $15.8 \%$ (95\% CI: 12.7-18.8\%) among those aged 40-49 years (Table 1). For each year of ageing, the rate increased by $4 \%$ $(P<0.001)$. This ageing trend, however, was more pronounced in women compared with men $(P=0.008)$. In other words, although diabetes was not generally more common in women than men $(P=0.861)$, the interaction of age and sex with diabetes prevalence was significantly positive, and diabetes mellitus was significantly more prevalent in elderly women $(P=$ 0.008) (Figure 1).

The standardized prevalence of diabetes was 24.0\% (95\% CI: 21.7-26.3\%) in urban and $30.2 \%$ (95\% CI: 22.29$38.17 \%$ ) in rural populations (Table 1). However, based on a multivariate logistic regression model (Table 2 ), the relationship between area of residence

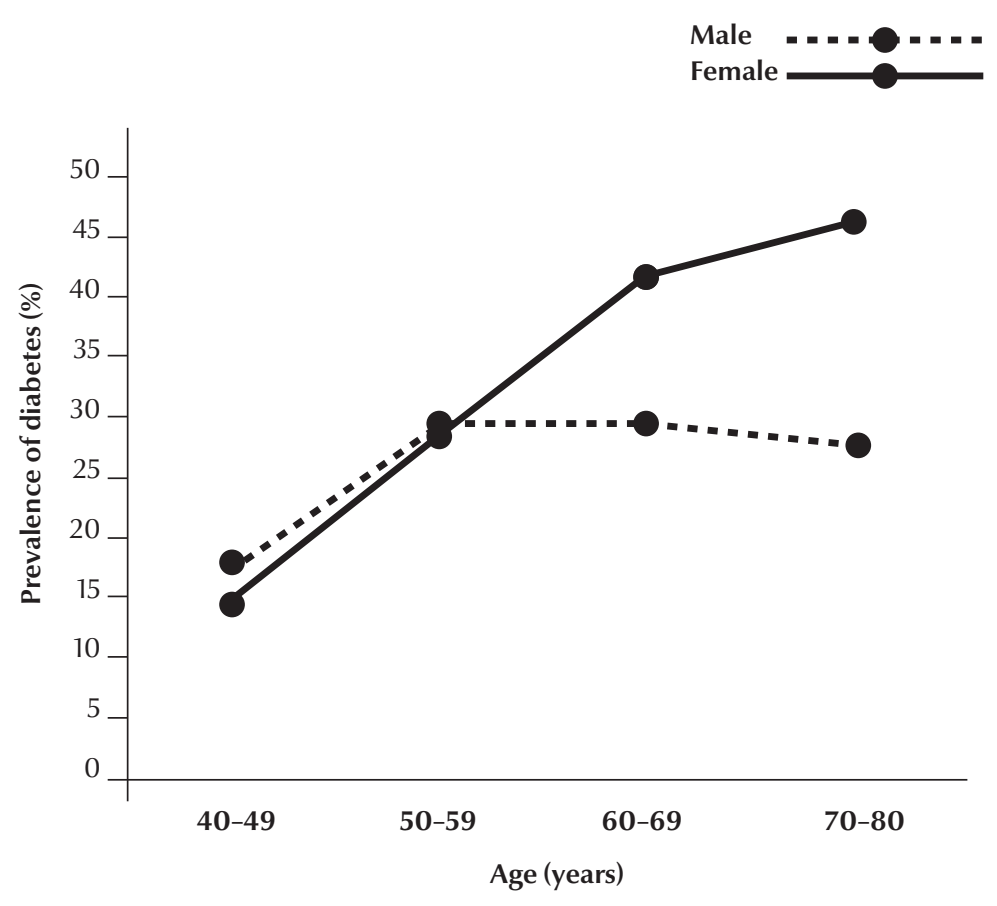

Figure 1 Prevalence of diabetes mellitus in the study sample, by age and sex

and diabetes mellitus was not statistically significant [odds ratio (OR) 1.4; 95\% CI: 0.9-2.0; $P=0.11$.

A significant relationship was found between level of education and prevalence of diabetes $(P<0.001)$. Diabetes prevalence was 36.3\% (95\% CI: 31.4-41.3\%) among illiterate participants, $25.7 \%$ (95\% CI: 22.6-28.8\%) in subjects with $<6$ years of education, $18.9 \%$ (95\% CI: $15.2-22.6 \%$ ) in those with 6-12 years of education and $17.9 \%$ (95\% CI: 13.4-22.4\%) in more than high school diploma-educated people.

As shown in Tables 1 and 2, the prevalence of diabetes was nearly 4 times higher in people with hypertension compared to those without hypertension ( $43.1 \%$ versus $13.8 \%$; OR 4.8 ; 95\% CI: 3.9-5.8).

The relationship between diabetes prevalence and BMI is illustrated in Table 1 and Table 2. Diabetes was significantly and consistently more common in obese subjects; the prevalence of diabetes mellitus rose steadily across BMI groups from $24.8 \%$ in normal weight people to $38.1 \%$ in obese class III.
The multivariate logistic regression model using a backward method applied to evaluate the simultaneous effect of all risk factors (Table 2), revealed that hypertension, older age, lower educational level and higher BMI were significantly associated with diabetes.

\section{Impaired fasting glucose}

IFG was found in 40 people, a standardized prevalence of $1.9 \%$ (95\% CI: $1.3-2.5 \%)$. The prevalence of IFG was not significantly associated with sex $(P=0.91)$ or age $(P=0.24)$ in a multiple logistic regression analysis (Table 3).

Figure 2 illustrates the prevalence of daily physical activity by glycaemic status. The frequency of exercise or occupational-related activity was lower in the IFG group (10.5\%) compared with the diabetes $(26.5 \%)$ or normoglycaemic groups (25.5\%). Compared with those with IFG, normoglycaemic people were 9 times more likely to have daily physical activity ( $\mathrm{OR}=8.9 ; 95 \%$ CI: 2.7-29.4). Patients with diabetes were 3 times more likely to be physically active (OR $=2.9$; 95\% CI: 0.9-9.1), 


\begin{tabular}{|c|c|c|}
\hline \multicolumn{3}{|c|}{$\begin{array}{l}\text { Table } 2 \text { Results of a multivariate logistic regression model for assessing the } \\
\text { simultaneous effect of some risk factors on diabetes mellitus in the study samp }\end{array}$} \\
\hline Variable & OR $(95 \% \mathrm{Cl})$ & $P$-value \\
\hline \multicolumn{3}{|l|}{ Age (years) } \\
\hline $40-49$ & Ref. & \\
\hline $50-59$ & $2.1(1.6-2.8)$ & $<0.001$ \\
\hline $60-69$ & $2.8(2.0-4.1)$ & $<0.001$ \\
\hline $70-80$ & $3.0(2.1-4.4)$ & $<0.001$ \\
\hline \multicolumn{3}{|l|}{ Sex } \\
\hline Male & Ref. & \\
\hline Female & $1.1(0.9-1.4)$ & 0.385 \\
\hline \multicolumn{3}{|l|}{ Area } \\
\hline Urban & Ref. & \\
\hline Rural & $1.4(0.9-2.0)$ & 0.117 \\
\hline \multicolumn{3}{|l|}{ Education (years) } \\
\hline Illiterate & Ref. & \\
\hline$<6$ & $0.6(0.5-0.8)$ & $<0.001$ \\
\hline $6-12$ & $0.4(0.3-0.5)$ & $<0.001$ \\
\hline$>12$ & $0.4(0.3-0.6)$ & $<0.001$ \\
\hline \multicolumn{3}{|l|}{ Hypertension } \\
\hline No & Ref. & \\
\hline Yes & $4.8(3.9-5.8)$ & $<0.001$ \\
\hline \multicolumn{3}{|l|}{$B M I$} \\
\hline Underweight & Ref. & \\
\hline Normal & $10.5(1.7-65.7)$ & 0.012 \\
\hline Overweight & $12.1(1.9-75.6)$ & 0.008 \\
\hline Obese class I & $12.4(1.9-80.8)$ & 0.008 \\
\hline Obese class II & $15.5(2.2-107.8)$ & 0.006 \\
\hline Obese class III & $19.5(2.7-141.5)$ & 0.003 \\
\hline
\end{tabular}

Ref. $=$ reference group; $O R=$ odds ratio; $C l=$ confidence interval. although the relationship was not statistically significant

\section{Laboratory findings}

The laboratory test results of participants with diabetes and IFG are shown in Table 4. The mean levels of haemoglobin and serum lipids were not significantly different comparing participants with diabetes and those with IFG (all $P$ values $>0.5$ ). Nevertheless $\mathrm{HbAlc}$ and urine albumin levels were significantly higher in participants with diabetes than those with IFG $(P<0.001$ and $P=0.032$ respectively).

\section{Discussion}

In situations in which routine data from a national information system are as yet unavailable it is important to conduct intermittent population-based studies to obtain updated information regarding the nation's health-care needs. In the current study, the prevalence of diabetes mellitus among the 40-80-year-old population in Yazd was found to be about $25 \%$, which shows a high prevalence of this disease. This finding is consistent with previous reports from the Islamic Republic of Iran; at the national level a diabetes prevalence of $16.2 \%$ and $16.8 \%$ was found in the $45-54$ and

\begin{tabular}{|c|c|c|c|c|c|}
\hline \multirow[t]{3}{*}{ Variable } & \multicolumn{3}{|c|}{ Impaired fasting glucose } & \multirow[b]{3}{*}{ OR $(95 \% \mathrm{Cl})$} & \multirow[b]{3}{*}{$P$-value } \\
\hline & \multicolumn{2}{|c|}{ Crude } & \multirow{2}{*}{$\begin{array}{c}\text { Standardized } \\
\%(95 \% \mathrm{CI})\end{array}$} & & \\
\hline & No. & $\%$ & & & \\
\hline \multicolumn{6}{|c|}{ Age (years) } \\
\hline $40-49$ & 16 & 2.0 & $1.9(1.2-3.0)$ & Ref. & \\
\hline $50-59$ & 16 & 2.3 & $2.3(1.3-3.9)$ & $1.1(0.6-2.2)$ & 0.731 \\
\hline $60-69$ & 5 & 1.5 & $1.5(0.6-3.5)$ & $0.7(0.2-2.0)$ & 0.547 \\
\hline $70-80$ & 3 & 1.2 & $1.2(0.4-3.7)$ & $0.6(0.2-2.0)$ & 0.396 \\
\hline \multicolumn{6}{|l|}{ Sex } \\
\hline Male & 19 & 1.9 & $1.8(1.1-3.1)$ & Ref. & \\
\hline Female & 21 & 1.9 & $1.9(1.3-2.9)$ & $1.0(0.5-1.9)$ & 0.91 \\
\hline Total & 40 & 1.9 & $1.9(1.3-2.5)$ & & \\
\hline
\end{tabular}

Ref. = reference group; $O R=$ odds ratio; $C l=$ confidence interval. 


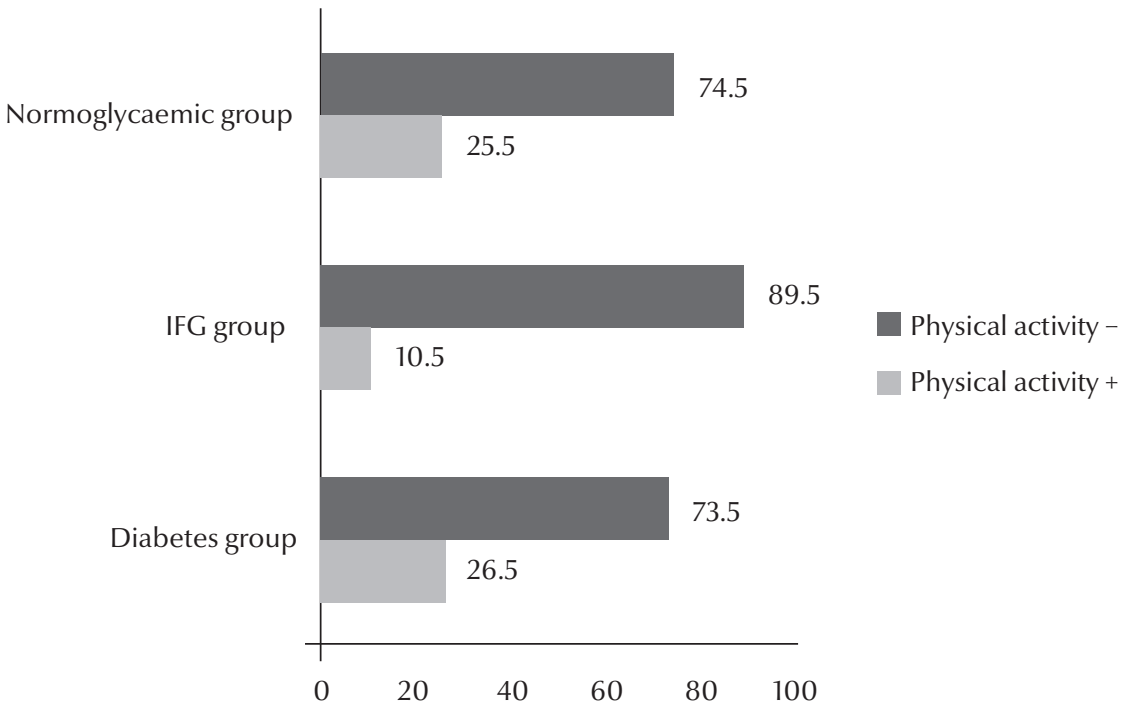

Figure 2 Prevalence of physical activity (\%) by glycaemic status in the study sample (normoglycaemie group $n=1511$; impaired fasting glucose group $n=40$; diabetes mellitus group $n=539$ )
55-64 year age groups respectively (16), while in the capital city, Tehran, diabetes prevalence was about $13 \%$ in the over 20-year-old population (8). In contrast, almost 2 decades before, the nationwide prevalence of diabetes was reported to be much lower, with an overall prevalence of $7.8 \%$ in those aged over 40 years (9), which is evidence for concern about a diabetes epidemic in this country. This finding could be related to many influences such as genetic and ethnic factors, inactive lifestyles and incorrect dietary habits.

Age-specific prevalence rates of diabetes in some neighbouring countries and also previous studies in the Islamic Republic of Iran are compared in Table 5 (8,16-20). As the table shows, the prevalence of diabetes in Yazd is greater than the average national level in Islamic

\begin{tabular}{|c|c|c|c|c|c|c|c|c|c|}
\hline \multirow[t]{3}{*}{ Parameter } & \multicolumn{4}{|c|}{ Impaired fasting glucose } & \multicolumn{4}{|c|}{ Diabetes mellitus } & \multirow[t]{3}{*}{$P$-value ${ }^{\text {a }}$} \\
\hline & \multicolumn{2}{|c|}{ Male $(n=19)$} & \multicolumn{2}{|c|}{ Female $(n=21)$} & \multicolumn{2}{|c|}{ Male $(n=254)$} & \multicolumn{2}{|c|}{ Female $(n=285)$} & \\
\hline & Mean & SD & Mean & SD & Mean & SD & Mean & SD & \\
\hline Haemoglobin $(\mathrm{g} / \mathrm{L})$ & 15.6 & 1.2 & 14.1 & 0.9 & 15.6 & 1.4 & 14.3 & 1.4 & 0.710 \\
\hline Glycated haemoglobin (mmol/mol) & 6.5 & 0.7 & 6.9 & 0.7 & 8.9 & 5.8 & 8.6 & 4.1 & $<0.001$ \\
\hline Microalbumin (mg/L) & 11.8 & 15.9 & 31.9 & 78.1 & 50.3 & 98.5 & 43.5 & 87.9 & 0.032 \\
\hline Triglycerides (mmol/L) & 2.5 & 1.3 & 1.8 & 0.8 & 2.3 & 1.6 & 2.1 & 1.2 & 0.594 \\
\hline HDL cholesterol (mmol/L) & 1.2 & 0.1 & 1.1 & 0.2 & 1.1 & 0.2 & 1.1 & 0.2 & 0.280 \\
\hline LDL cholesterol (mmol/L) & 3.6 & 1.2 & 4.0 & 1.5 & 3.4 & 1.1 & 3.9 & 1.1 & 0.437 \\
\hline Total cholesterol (mmol/L) & 5.8 & 1.1 & 5.9 & 1.6 & 5.5 & 1.3 & 6.0 & 1.2 & 0.429 \\
\hline
\end{tabular}

${ }^{a}$ Based on multiple logistic regression, adjusted for age and sex.

$S D=$ standard deviation; $L D L=$ low-density lipoprotein; $H D L=$ high-density lipoprotein .

\begin{tabular}{|c|c|c|c|c|}
\hline \multirow[t]{2}{*}{ Country (reference) } & \multicolumn{4}{|c|}{ Prevalence of diabetes mellitus (\%) } \\
\hline & $40-49$ years & 50-59 years & 60-69 years & $\geq 70$ years \\
\hline Korea (17) & 17.0 & 23.2 & 33.8 & 19.3 \\
\hline Turkey (18) & 3.4 & 9.7 & 10.7 & 18.5 \\
\hline China (19) ${ }^{\mathrm{a}}$ & 3.2 & 5.5 & 8.5 & - \\
\hline Pakistan $(20)^{b}$ & 6.7 & 5.2 & 5.0 & 6.3 \\
\hline Islamic Republic of Iran (national) (16) & 6.8 & 12.9 & 16.8 & - \\
\hline Islamic Republic of Iran (capital city) (8) & 14.1 & 25.6 & 32.1 & 33.7 \\
\hline Islamic Republic of Iran (current study) & 15.8 & 28.9 & 35.0 & 37.0 \\
\hline
\end{tabular}

${ }^{a}$ Age groups were 5 years less than those in the column headers; ${ }^{b}$ Age groups were 5 years more than those in the column headers. 
Republic of Iran and those of the nearby countries. Conversely, it is comparable to the metropolitan urban population of the Islamic Republic of Iran (16).

In most studies, the prevalence of diabetes is higher in urban populations (16,21-23). Nevertheless, we observed a higher prevalence among participants living in rural areas. It should be mentioned that our classification of urban/ rural settings was based on the Iranian National Statistical Office. The proportion of people living in rural areas in this district is relatively low compared with other districts and the people live closer to urban residential areas. This may have had some effect on their lifestyle and nutrition and consequently resulted in a higher prevalence of diabetes. Furthermore, other studies from Islamic Republic of Iran and a study in India have reported an increasing trend of diabetes among rural dwellers $(24,25)$. Although this finding should be confirmed by more extended studies with higher sample sizes of rural populations, it may raise some concerns regarding the importance of preventive and management strategies in rural as well as urban settings in developing countries.

Although the total prevalence of diabetes was not significantly different between men and women, diabetes was more common in older women in this study, which illustrates that an interaction between age, sex and diabetes exists. This findings is not surprising because men have higher all-cause mortality rates than women at older ages. A systematic review showed a similar pattern in South Africa and among subjects with Indian ethnicity, but diabetes was significantly higher in men in the Middle and Eastern African countries (26). Further studies are required to investigate the relationship of diabetes mellitus and sex.

In the current study the proportion of known cases of diabetes was relatively high and comprised more than $89 \%$ of the total cases with diabetes. This is an unusual finding because in previous studies from the Islamic Republic of Iran only $50-70 \%$ of patients were aware of their diabetes $(21,27)$. It should be mentioned that a national programme for the prevention and control of type 2 diabetes was introduced and implemented in the Islamic Republic of Iran since 1996 (28,29). According to this programme, community members atrisk for diabetes are detected and periodically screened by the primary and secondary health-service providers in the different provinces including Yazd. This may explain the small proportion of undiagnosed diabetes in our study.

A correlation between diabetes and obesity has been confirmed by many large epidemiological studies (30), and such a relationship was observed in our study too. In addition, the statistically significant association between diabetes and hypertension in our study was consistent with previous studies in this field $(31,32)$.

As in some other studies, in India (33), Germany (34) and Saudi Arabia (35), we found a correlation between lower education levels and higher prevalence of diabetes. This emphasizes the importance of health promotion and education programmes for illiterate or less educated people.

There were some limitations to the current study. Due to logistic and financial limitations, instead of 2 venous blood samples, the initial screening sample was obtained from a capillary vessel and tested by a valid glucometry method. Venous blood tests were only obtained from subjects with suspected or definite diabetes. To increase the sensitivity of diagnosis, all those with a FBS $\geq 5.94 \mathrm{mmol} / \mathrm{L}$ rather than FBS $\geq 6.94 \mathrm{mmol} / \mathrm{L}$ in glucometry were considered as suspected diabetes and a complete blood test was taken to confirm the diagnosis of diabetes mellitus. In addition, laboratory tests were only done for participants with diabetes mellitus. Therefore, it was not possible to compare biochemical metabolic risk factors such as dyslipidaemia, microalbumin and HbAlc among participants with and without diabetes. Finally, only people aged $40-80$ years were recruited into this study. Due to the increasing number of young people with diabetes and the serious burden of early-onset diabetes mellitus, future surveys need to study the younger age groups too.

\section{Acknowledgements}

Funding: Financial support was obtained from the Department of Noncommunicable Disease of the Ministry of Health.

Competing interests: None declared.

\section{References}

1. Wild S, Roglic G, Green A, Sicree R, King H. Global prevalence of diabetes: estimates for the year 2000 and projections for 2030. Diabetes Care. 2004 May;27(5):1047-53. PMID:15111519

2. Pompili M, Lester D, Innamorati M, De Pisa E, Amore M, Ferrara $C$, et al. Quality of life and suicide risk in patients with diabetes mellitus. Psychosomatics. 2009 Jan-Feb;50(1):16-23. PMID:19213968

3. Rato Q. Diabetes mellitus: a global health problem. Rev Port Cardiol. 2010 Apr;29(4):539-43. PMID:20734574
4. Hewitt J, Smeeth L, Bulpitt CJ, Fletcher AE. The prevalence of Type 2 diabetes and its associated health problems in a community-dwelling elderly population. Diabet Med. 2009 Apr;26(4):370-6. PMID:19388966

5. Guariguata L, Whiting DR, Hambleton I, Beagley J, Linnenkamp U, Shaw JE. Global estimates of diabetes prevalence for 2013 and projections for 2035. Diabetes Res Clin Pract. 2014 Feb;103(2):137-49. PMID:24630390

6. Javanbakht M, Baradaran HR, Mashayekhi A, Haghdoost AA, Khamseh ME, Kharazmi E, et al. Cost-of-illness analysis of 
type 2 diabetes mellitus in Iran. PLoS One. 2011;6(10):e26864. PMID:22066013

7. Haghdoost AA, Rezazadeh-Kermani M, Sadghirad B, Baradaran HR. Prevalence of type 2 diabetes in the Islamic Republic of Iran: systematic review and meta-analysis. East Mediterr Health J. 2009 May-Jun;15(3):591-9. PMID:19731775

8. Hadaegh F, Bozorgmanesh MR, Ghasemi A, Harati H, Saadat N, Azizi F. High prevalence of undiagnosed diabetes and abnormal glucose tolerance in the Iranian urban population: Tehran Lipid and Glucose Study. BMC Public Health. 2008;8:176. PMID:18501007

9. Amini M, Afshin-Nia F, Bashardoost N, Aminorroaya A, Shahparian M, Kazemi M. Prevalence and risk factors of diabetes mellitus in the Isfahan city population (aged 40 or over) in 1993. Diabetes Res Clin Pract. 1997 Dec;38(3):185-90. PMID:9483385

10. Heidari K, Sajjadi SA, Hadian R, Hadi S, Hosseinkhani R, Amini $\mathrm{S}$, et al. Establishment of Health Clinics as Mass Screening and Referral Systems for Chronic Non-communicable Diseases in Primary Health Care. Int J Prev Med. 2012 Mar;3(3):173-80. PMID:22448310

11. Katibeh M, Ziaei H, Pakravan M, Dehghan MH, Ramezani A, Amini H, et al. The Yazd Eye Study-a population-based survey of adults aged $40-80$ years: rationale, study design and baseline population data. Ophthalmic Epidemiol. 2013;20(1):61-9. PMID:23350557

12. Fauci AS. Harrison's principles of internal medicine. New York (NY): McGraw-Hill; 2008.

13. Kuzuya T, Nakagawa S, Satoh J, Kanazawa $Y$, Iwamoto $Y$, Kobayashi M, et al.; Committee of the Japan Diabetes Society on the diagnostic criteria of diabetes mellitus. Report of the Committee on the classification and diagnostic criteria of diabetes mellitus. Diabetes Res Clin Pract. 2002 Jan;55(1):65-85. PMID:11755481

14. Forouhi NG, Balkau B, Borch-Johnsen K, Dekker J, Glumer C, Qiao Q, et al.; EDEG. The threshold for diagnosing impaired fasting glucose: a position statement by the European Diabetes Epidemiology Group. Diabetologia. 2006 May;49(5):822-7. PMID:16525842

15. Chobanian AV, Bakris GL, Black HR, Cushman WC, Green LA, Izzo JL Jr, et al.; Joint National Committee on Prevention, Detection, Evaluation, and Treatment of High Blood Pressure. National Heart, Lung, and Blood Institute; National High Blood Pressure Education Program Coordinating Committee. Seventh report of the Joint National Committee on Prevention, Detection, Evaluation, and Treatment of High Blood Pressure. Hypertension. 2003 Dec;42(6):1206-52. PMID:14656957

16. Esteghamati A, Gouya MM, Abbasi M, Delavari A, Alikhani $\mathrm{S}$, Alaedini F, et al. Prevalence of diabetes and IFG in the adult population of Iran: National Survey of Risk Factors for Non-Communicable Diseases of Iran. Diabetes Care. 2008 Jan;31(1):96-8. PMID:17921357

17. Lee JE, Jung SC, Jung GH, Ha SW, Kim BW, Chae SC, et al. Prevalence of Diabetes Mellitus and Prediabetes in Dalseong-gun, Daegu City, Korea. Diabetes Metab J. 2011 Jun;35(3):255-63. PMID:21785746

18. Ozdemir L, Topçu S, Nadir I, Nur N, Arslan S, Sümer H. The prevalence of diabetes and impaired glucose tolerance in Sivas, Central Anatolia, Turkey. Diabetes Care. 2005 Apr;28(4):7958. PMID:15793175

19. Hu D, Sun L, Fu P, Xie J, Lu J, Zhou J, et al. Prevalence and risk factors for type 2 diabetes mellitus in the Chinese adult population: the InterASIA Study. Diabetes Res Clin Pract. 2009 Jun;84(3):288-95. PMID:19442859

20. Shera AS, Jawad F, Maqsood A. Prevalence of diabetes in Pakistan. Diabetes Res Clin Pract. 2007 May;76(2):219-22. PMID:17005289
21. Esteghamati A, Meysamie A, Khalilzadeh O, Rashidi A, Haghazali M, Asgari F, et al. Third national Surveillance of Risk Factors of Non-Communicable Diseases (SuRFNCD-2007) in Iran: methods and results on prevalence of diabetes, hypertension, obesity, central obesity, and dyslipidemia. BMC Public Health. 2009;9:167. PMID:19480675

22. Satman I, Yilmaz T, Sengül A, Salman S, Salman F, Uygur S, et al. Population-based study of diabetes and risk characteristics in Turkey: results of the Turkish Diabetes Epidemiology Study (TURDEP). Diabetes Care. 2002 Sep;25(9):1551-6. PMID:12196426

23. Bos M, Agyemang C. Prevalence and complications of diabetes mellitus in Northern Africa, a systematic review. BMC Public Health. 2013;13:387. PMID:23617762

24. Sadeghi M, Talaei M, Parvaresh Rizi E, Dianatkhah M, Oveisgharan S, Sarrafzadegan N. Determinants of incident prediabetes and type 2 diabetes in a 7-year cohort in a developing country: The Isfahan Cohort Study. J Diabetes. 2014 Oct 28 PMID:25350916

25. Shrivastava SR, Ghorpade AG. High prevalence of type 2 diabetes melitus and its risk factors among the rural population of pondicherry, South India. J Res Health Sci. 2014;14(4):258-63. PMID:25503279

26. Hilawe EH, Yatsuya H, Kawaguchi L, Aoyama A. Differences by sex in the prevalence of diabetes mellitus, impaired fasting glycaemia and impaired glucose tolerance in sub-Saharan Africa: a systematic review and meta-analysis. Bull World Health Organ. 2013 Sep 1;91(9):671-682D. PMID:24101783

27. Delavari A, Forouzanfar MH, Alikhani S, Sharifian A, Kelishadi R. First nationwide study of the prevalence of the metabolic syndrome and optimal cutoff points of waist circumference in the Middle East: the national survey of risk factors for noncommunicable diseases of Iran. Diabetes Care. 2009 Jun;32(6):1092-7. PMID:19279302

28. Azizi F, Gouya MM, Vazirian P, Dolatshahi P, Habibian S. The diabetes prevention and control programme of the Islamic Republic of Iran. East Mediterr Health J. 2003 SepNov;9(5-6):1114-21. PMID:16450545

29. Azizi F, Guoya MM, Vazirian P, Dolatshati P, Habbibian S. Screening for type 2 diabetes in the Iranian national programme: a preliminary report. East Mediterr Health J. 2003 Sep-Nov;9(5-6):1122-7. PMID:16450546

30. Colosia AD, Palencia R, Khan S. Prevalence of hypertension and obesity in patients with type 2 diabetes mellitus in observational studies: a systematic literature review. Diabetes Metab Syndr Obes. 2013;6:327-38. PMID:24082791

31. Jiménez-Corona A, Rojas R, Gómez-Pérez FJ, Aguilar-Salinas CA. Early-onset type 2 diabetes in a Mexican survey: results from the National Health and Nutrition Survey 2006. Salud Publica Mex. 2010;52 Suppl 1:S27-35. PMID:20585726

32. Zellweger MJ, Hachamovitch R, Kang X, Hayes SW, Friedman JD, Germano G, et al. Prognostic relevance of symptoms versus objective evidence of coronary artery disease in diabetic patients. Eur Heart J. 2004 Apr;25(7):543-50. PMID:15120050

33. Ajay VS, Prabhakaran D, Jeemon P, Thankappan KR, Mohan V, Ramakrishnan L, et al. Prevalence and determinants of diabetes mellitus in the Indian industrial population. Diabet Med. 2008 Oct;25(10):1187-94. PMID:19046197

34. Heidemann C, Kroll L, Icks A, Lampert T, Scheidt-Nave C. Prevalence of known diabetes in German adults aged 25-69 years: results from national health surveys over 15 years. Diabet Med. 2009 Jun;26(6):655-8. PMID:19538243

35. Al-Baghli NA, Al-Ghamdi AJ, Al-Turki KA, Al Elq AH, El-Zubaier AG, Bahnassy A. Prevalence of diabetes mellitus and impaired fasting glucose levels in the Eastern Province of Saudi Arabia: results of a screening campaign. Singapore Med J. 2010 Dec;51(12):923-30. PMID:21221496 